\title{
Social Network Approach To Organizational Learning
}

Miha Škerlavaj, (Email: miha.skerlavaj@ef.uni-lj.si), University of Ljubljana, Slovenia

Vlado Dimovski, (E-mail: vlado.dimovski@ef.uni-lj.si), University of Ljubljana, Slovenia

\begin{abstract}
Organizational learning is one of the most promising concepts and propulsive areas of research in modern managerial literature. So far, it was proved that higher-level organizational learning contributes to organizational performance. Research question that remains explained inadequately is how learning occurs. Based on exploratory social network analysis conducted on a learning network within a software company, we offer eight propositions. First, the greater the experience of the employee in a certain field, the bigger the probability that co-workers will seek to learn from this person. Then, respectively, physical proximity (e.g. shared office or geographical proximity), similarity in level of expertise, and complementarities in personal characteristics augment the probability that co-workers will learn from each-other. Next, network size and age affect its density. Finally, knowledge-based organizations seem to have cohesive structure of relationships among their members. Further confirmatory research is needed in order to develop and test propositions offered.
\end{abstract}

\section{INTRODUCTION}

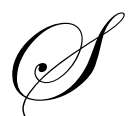

ocial networks are seen as a specific set of linkages among a defined set of persons, with the additional property that the characteristics of these linkages as a whole may be used to interpret the social behaviour of the persons involved (Mitchell, 1969). The social network approach views organizations in society as a system of objects (e.g. people, groups, and organizations) joined by variety of relationships. Not all pairs of objects are directly joined, and some are joined by multiple relationships. Network analysis is concerned with the structure and patterning of these relationships and seeks to identify both their causes and consequences (Tichy et al, 1979). The network analysis examines system-wide effects instead of the characteristics of actors. As an alternative to viewing a relationship in isolation, it treats a relationship as a gateway to other relationships through which knowledge or resources may be reached (Easton, 1992).

The Learning Network Theory (Van der Krogt, 1995, 1998; Poell et al, 2000) describes the way learning is organized in the context of work organizations. According to this theory, a learning network is operating in every organization. Learning networks are not limited to network-type organizations, or to matrix organizations, or to teambased organizations. People learn in every organization, even in a hierarchical one or chaotic one, and the learning network merely represents how the learning is organized. A learning network consists of the various learning activities organized by the members in the organization. Three main components are (1) learning processes - development of learning policies, development of learning programmes, and execution of learning programmes; (2) learning structures - content structure, organizational structure, and learning climate; and (3) actors - employees, managers etc. Learning networks take various shapes depending both on actor dynamics and work characteristics. Four various theoretical types of learning networks and their traits are presented in Table 1. 
Table 1: Four Theoretical Types Of Learning Networks

\begin{tabular}{|c|c|c|c|c|}
\hline \multicolumn{5}{|c|}{ Learning Networks } \\
\hline & Liberal & Vertical & Horizontal & External \\
\hline Learning processes & Single activities & Linearly planned & Organically-oriented & $\begin{array}{l}\text { Externally } \\
\text { co-ordinated }\end{array}$ \\
\hline $\begin{array}{l}\text { Development of } \\
\text { learning policies }\end{array}$ & Implicit & Planning & Learning & Inspiring \\
\hline $\begin{array}{l}\text { Development of } \\
\text { learning programmes }\end{array}$ & Collecting & Designing & Developing & Innovative \\
\hline $\begin{array}{l}\text { Execution of learning } \\
\text { programmes }\end{array}$ & Self-directing & Guiding & Counselling & Advisory \\
\hline \multicolumn{5}{|l|}{ Learning Structures } \\
\hline $\begin{array}{l}\text { Content structure } \\
\text { (profile) }\end{array}$ & $\begin{array}{l}\text { Unstructured } \\
\text { (individually-oriented) }\end{array}$ & $\begin{array}{l}\text { Structured } \\
\text { (task-or-function- } \\
\text { oriented) }\end{array}$ & $\begin{array}{l}\text { Open or thematic } \\
\text { (organization or } \\
\text { problem-oriented) }\end{array}$ & $\begin{array}{l}\text { Methodical } \\
\text { (profession-oriented) }\end{array}$ \\
\hline $\begin{array}{l}\text { Organizational } \\
\text { structure (relations) }\end{array}$ & $\begin{array}{l}\text { Loosely coupled } \\
\text { (contractual) }\end{array}$ & $\begin{array}{l}\text { Centralized } \\
\text { (formalized) }\end{array}$ & $\begin{array}{l}\text { Horizontal } \\
\text { (egalitarian) }\end{array}$ & $\begin{array}{l}\text { Externally directed } \\
\text { (professional) }\end{array}$ \\
\hline Learning climate & Liberal & Regulative & Integrative & Inspiring \\
\hline \multicolumn{5}{|c|}{ Supporting Studies } \\
\hline Authors & $\begin{array}{l}\text { Bloch and Bates, } \\
\text { 1995; Filipczak, 1995; } \\
\text { Andrews and } \\
\text { Herschel, } 1996\end{array}$ & $\begin{array}{l}\text { Wilson and Cervero, } \\
1997\end{array}$ & Senge, 1990 & Poell et al, 2000 \\
\hline Findings & $\begin{array}{l}\text { Likely to emerge in } \\
\text { organizations with } \\
\text { strong notion of } \\
\text { employee } \\
\text { empowerment and } \\
\text { tendency towards } \\
\text { liberalization. }\end{array}$ & $\begin{array}{l}\text { Common in large } \\
\text { organizations. } \\
\text { Despite unpopularity } \\
\text { of Taylorism, still } \\
\text { plays important role in } \\
\text { organizational reality. }\end{array}$ & $\begin{array}{l}\text { Gained popularity } \\
\text { through extensive } \\
\text { literature on learning } \\
\text { organizations. } \\
\text { Advocates total } \\
\text { integration of learning } \\
\text { and work in teams. }\end{array}$ & $\begin{array}{l}\text { Common in } \\
\text { environments where } \\
\text { employees have } \\
\text { strong orientation } \\
\text { towards their } \\
\text { professional field. } \\
\text { Hard to control. }\end{array}$ \\
\hline
\end{tabular}

Source: Adapted from Van der Krogt, 1995, 1998 and Poell et al, 2000.

\section{RESEARCH METHODOLOGY}

In order to understand learning networks, we conducted a social network analysis (SNA) of a software company. SNA provides a visualized graphic and mathematical analysis of a complex human interaction and is "the mapping and measuring of relationships and flows between people, groups, organizations, computers or other information/knowledge processing entities' (Krebs, 2002). The nodes in network are the people and groups while the links represent relationships or flows between the nodes. Rather than focusing on permanent attributes of people, objects or events, the social network perspective views characteristics of those people as arising out of relational process (Wasserman and Faust, 1994).

The firm had 93 employees in three countries (geographical units: Slovenia, Croatia and Serbia \& Montenegro). Company was founded in 1989, subsidiary in Croatia in 2000 and joint venture in Serbia \& Montenegro in 2003. It has had $€ 4.2$ million turnover in 2004, average annual growth of $28 \%$ in period $1995-2003$. Their core business is software development, IT \& business consulting and maintenance \& support. Three main business units (BU) are Enterprise Resource Planning Solutions, Industry Solutions, and Banking.

Fifty-nine respondents work in Ljubljana (Slovenia), 11 in Zagreb (Croatia) and another 11 in Belgrade (Serbia \& Montenegro). For a knowledge-based organization it is important to have adequate educational structure. In our case, $56.7 \%$ of respondents have a university degree or more (even one $\mathrm{PhD}$ ), while significant portion of secondary-school graduates work as students and are still in the process of formal education. 74\% of respondents are male, average tenure in company is 38.9 months (with variations from one month to 15 years). Company has a relatively flat organizational structure with just a few hierarchical levels and wide control spans. $60.5 \%$ of all 
respondents declared themselves as members of non-management, $8.6 \%$ as line management, $6.2 \%$ as middle management, $17.3 \%$ as project management, and $7.4 \%$ as top management. The most frequent function is programmer (software developer, tester, software architect) with $34.6 \%$ of respondents, followed by consultants - representing $24.7 \%$ of respondents and project managers with $9.9 \%$.

We measured learning network by asking respondents about the people in their organization they learn the most from. They were given a coding scheme with names and IDs of all employees and co-workers within the company. Level of learning was represented on one to five scale where value 1 means 'I do not learn from this person' and 5 signifies 'I learn a lot from this person'. 93 units in the network received questionnaire via e-mail in December 2004. After one month and a second call, we obtained 81 fully completed questionnaires. Twelve members of organization that failed to participate were either on parental leave or recent newcomers, estimated not to have significant impact on current state of learning network within the company. Recoding was made so that responses that had value on the scale lower than 3 (meaning that they learn little or very little from that person) were given value 0 and other value 1 . Hence, response rate accounted for $87.1 \%$. Data validity and reliability were assured using an indepth interview with a member of middle management, who confirmed the fit between his subjective view on the matter and the results obtained from social Network Analysis (Sna).

\section{ANALYSES}

We observed a directed inter-personal network with three-business and three-geographical unit organization and measured a relationship 'learning from' (Figure 1). Software used for data analysis was Pajek 1.04 (Batagelj and Mrvar, 2005; de Nooy et al, 2005). The arrow directing for instance from person 52 to person 66 means that person 52 learns from person 66. Shapes of units represent their location where by the circle is Ljubljana, the triangle Zagreb and the square Belgrade. Beside that, numbers in brackets next to each unit stand for business unit that they work at (1 means BU Navision, 2 - BU Industry Solutions, 3 - BU Banking solutions, 4 - PR and Marketing, 5 - top management office and 6 - data not available).

The company invests heavily into development of informal relationships among employees, also for subsidiaries. Despite this fact, transfer of tacit knowledge is restricted mainly to the exchange of ideas about certain expert problems, while transfer of explicit knowledge is confined to start-up support with projects. A probable reason for such a situation is the fact that employees in Ljubljana are under a large pressure, and the budget for cooperation is not defined. Hence, it all happens on a voluntary basis. The company might reconsider the reward system in order to provide incentives to cooperation and learning, given the proven fact that organizations with higher level of organizational learning gain in terms of increased level of return on investments, value added per employee, improved quality of relationships with employees, customers and main partners (Dimovski and Škerlavaj, 2004).

Figure 1 is indicative of a relatively strong inter-connectedness within three different locations, while connections among them are quite rare. For instance, within Croatian subsidiary (bottom of the figure, triangular shapes), only three persons learn from co-workers in Ljubljana (central part of the figure, round shapes), while in Belgrade (upper right part of the Figure 1, square shapes), only two such persons exist. Learning in other direction is even scarcer. It is interesting that there are no learning relationships between the Belgrade and the Zagreb subsidiary. Partially, it can be explained with the fact, that the Belgrade unit was established later. Explicit knowledge was transferred to Belgrade above all from the Ljubljana personnel, who still control the majority of their operations. At the same time, most of 'international' projects come to Belgrade from Ljubljana. These kinds of projects are known to have the strongest impact on learning and knowledge transfer.

Figure 1 shows that learning among various business units is much more present as it was among various geographical units (i.e. countries). Problem of insufficient horizontal communication, significant for traditional, functional or divisional organizational structure, is well resolved in the case observed. This can be assigned to intensive informal contacts among leaders and age similarity of employees. 
Input degrees of certain vertex in our case represent the number of people within the organization that learn from that certain person. Output degrees on the other hand answer the question how many co-workers a particular person learns from. Analysis of input and output degrees of members of the learning network (Appendix A) revealed several issues. Members (i.e. units) with the largest input degree are people who have the most experience in the field. Other members of the Ljubljana sub-network learn the most from most experienced and competent co-workers, who are at the same time also directors of business units or project managers, in one case even a member of top management team.

The same goes for Zagreb and Belgrade - experience is the strongest criteria of being a source of learning for other people. Common characteristic of the people who are most wanted as a source of learning (i.e. have the highest input degree) in Ljubljana is on average 66 months of tenure within the company, which is two times the average of all employees. It needs to be emphasized that the majority of people with high input degree belongs to middle management and have up to 10 years of tenure within the company, while others (with two to three years tenure) were top human resources of competing companies. They were headhunted to this particular company and after a few months of adaptation took over leading positions. Employees that are the least often a source of learning are either beginners, or students or administrative personnel. According to the interview, only in few cases, low input degree can be assigned to high specialization or introverted character of the employee. On this basis we offer research proposition in need for further empirical investigation:

P1: Greater the experience of the employee in a certain field, the bigger the probability that co-workers will seek to learn from this person.

Analysis of strong components within the network shows that learning occurs mainly among business units on one hand ERP Solutions, and on the other Industry and Banking Solutions. SNA also revealed four cliques ${ }^{1}$ on three vertices. In other words, there are four cases where three people mutually learn from each other. Interestingly, in one case, these are people who work in the same room, while in other three cases, these are persons who are at a similar level of expertise and complement themselves by personal characteristics and knowledge they possess. On this basis we offer another set of propositions:

P2: $\quad$ Physical proximity (e.g. shared office or geographical proximity) augments the probability that co-workers will learn from each other.

P3: Similarity in the level of expertise augments the probability that co-workers will learn from each other.

P4: Complementarities in personal characteristics increase the probability that co-workers will learn from each other.

P5: Complementarities in knowledge possessed augment the probability that co-workers will learn from each other.

In Table 2 network and sub-networks densities are presented. Density is numeric value between 0 and 1. Network would have value 1 when everybody would learn from everybody else and 0 when there would be no relationship among the members of the network. Not surprisingly, smaller networks are denser than larger subnetworks. Perhaps it is notable that the Zagreb unit is denser than the one from Belgrade (being of equal size). This can be contributed to the fact that relationships need time to establish and that the Belgrade unit is relatively novel. According to the gender criteria, no significant differences in sub-network density exist, while differences among BU sub-network density can be assigned to differences in their size. The same can be said also for hierarchical position. Research propositions offered are:

\footnotetext{
${ }^{1}$ For readers interested in the social network analysis methodology we suggest Wasserman, S., Faust, K. (1994): Social Network Analysis, Cambridge University Press and Nooy, W. de, Mrvar, A., Batagelj, V. (2005): Exploratory social network analysis with Pajek, New York: Cambridge University Press.
} 
P6: Network size affects the density of networks.

P7: Network age affects the density of networks.

Table 2: Network And Sub-Network Densities

\begin{tabular}{|c|c|c|c|c|c|}
\hline Network & \multicolumn{5}{|c|}{ Density } \\
\hline $\begin{array}{l}\text { Whole learning } \\
\text { network }\end{array}$ & \multicolumn{5}{|c|}{0,046} \\
\hline $\begin{array}{l}\text { Sub-networks: } \\
\text { Partition Criteria }\end{array}$ & \multicolumn{5}{|c|}{ Sub-network Density (Sub-network Size-number Of Vertices Included) } \\
\hline $\begin{array}{l}\text { Geographical } \\
\text { location }\end{array}$ & $\begin{array}{l}\text { Ljubljana: } \\
0,068(59) \\
\end{array}$ & $\begin{array}{c}\text { Zagreb: } \\
0,25(11)\end{array}$ & $\begin{array}{l}\text { Belgrade: } \\
0,19(11) \\
\end{array}$ & & \\
\hline Gender & $\begin{array}{c}\text { Male: } \\
0,0541(60)\end{array}$ & $\begin{array}{c}\text { Female: } \\
0,0544(21)\end{array}$ & & & \\
\hline Business unit & $\begin{array}{c}\text { ERP Solutions: } \\
0,088(38) \\
\end{array}$ & $\begin{array}{c}\text { Industry solutions: } \\
0,117(18) \\
\end{array}$ & $\begin{array}{l}\text { Banking: } \\
0,19(11) \\
\end{array}$ & $\begin{array}{c}\text { Other } \\
0,082(14) \\
\end{array}$ & \\
\hline $\begin{array}{l}\text { Hierarchical } \\
\text { position }\end{array}$ & $\begin{array}{c}\text { Top management: } \\
0,25(6)\end{array}$ & $\begin{array}{c}\text { Middle management: } \\
0,28(5)\end{array}$ & $\begin{array}{c}\text { Project management: } \\
0,07(14)\end{array}$ & $\begin{array}{c}\text { Line management: } \\
0,041(7)\end{array}$ & $\begin{array}{l}\text { Personnel: } \\
0,038(49)\end{array}$ \\
\hline
\end{tabular}

When observing brokerage roles (Appendix B), we scrutinize triads of vertices and relationships among them according to the group that they belong to. We analysed brokerage roles according to criteria of geographical location, which proved to have the strongest impact on learning in preceding examination of data gathered. Coordinator is the person who connects two members of the same group, who do not learn directly from each other. Learning flow goes indirectly through coordinator. Most often (i.e. 71 times) this role is present with unit 24 (director of ERP Solutions development). This is no surprise given the fact that this is one of his duties and that coordination is one of his explicit responsibilities. Another six persons play this role more that 20 times, while 27 persons never play role of coordinator.

Itinerant broker is a role similar to coordinator, with this distinction, that this person does not belong to the same group as the other two. Put differently, itinerant broker returns knowledge to the group where he got it from in the first place. All four itinerant brokers are members of subsidiaries and are co-workers who participate on common projects with members from the central office in Ljubljana. Ten members of organization play the role of gatekeeper. They learn something from the member of their sub-network and then pass it on to a member of another subgroup. Only one person is liaison, who connects members of various subgroups, while he/she does not belong to any one of them. In our case, unit 24 (i.e. director of ERP development) learns from person 67bg from the Belgrade unit and then pass it on to person 93zg from Zagreb.

When trying to establish the most important co-workers in organizational learning networks, another measure can be employed. Between-ness centrality of a vertex is important for communication networks, where learning networks can be included as well. In technical terms, it is the proportion of all geodesics between pairs of other vertices which include this vertex (de Nooy et al, 2005). In plain words, it points to the members of networks who lie on the shortest routes among pairs of units within the networks and as such, have control over information flow. Table 3 shows 15 most important vertices according to between-ness centrality criteria. As expected from brokerage roles analysis, the most important vertex is unit 24 (i.e. director of ERP solutions development), followed by unit 42 (i.e. director of business unit). Both of them belong to top and middle management. This points out to the fit among formal and informal organizational structure from the learning perspective, meaning that knowledge in this organization truly means power. The first member of personnel, programmer (vertex 34), is in the third place. The most central units from the Belgrade and Zagreb subsidiaries are on eleventh and fifteenth place. 88zg is consultant, while 67bg is a member of top management team.

Another interesting question is the structure of relationships among vertices. Block modelling is concerned with searching of groups within the network that have similar structure of relationships. Wasserman and Faust (1994) define various theoretically relevant block models. Among others those are cohesive groups, model centre-periphery, central model and hierarchical model. Knowledge-based organizations should have, according to previous studies 
(Lazega, 1992), a structure of relationships closer to cohesive groups, while large (i.e. mainly manufacturing) systems are supposed to look like hierarchical models.

Table 4: Fifteen Most Important Vertices According To Between-Ness-Centrality $\left(C_{B}\right)$ Criteria

\begin{tabular}{|c|c|c|}
\hline Rank & $\mathbf{C}_{\mathbf{B}}$ & Vertex name \\
\hline 1 & 0.3359547 & 24 \\
\hline 2 & 0.2100350 & 32 \\
\hline 3 & 0.1871086 & 30 \\
\hline 4 & 0.1550001 & 43 \\
\hline 5 & 0.1511280 & 66 \\
\hline 6 & 0.1446633 & 5 \\
\hline 7 & 0.1442411 & 33 \\
\hline 8 & 0.1437896 & 70 \\
\hline 9 & 0.1430381 & 41 \\
\hline 10 & 0.0843328 & $88 \mathrm{zg}$ \\
\hline 11 & 0.0834852 & $93 \mathrm{zg}$ \\
\hline 13 & 0.0797269 & 68 \\
\hline 14 & 0.0790968 & 19 \\
\hline 15 & 0.0721198 & $67 \mathrm{bg}$ \\
\hline
\end{tabular}

Cohesive groups have strong connections within each group and are virtually without connections among different groups. Centre-periphery has one central group within which units are strongly connected and are also connected to members of other groups. Other peripheral groups are connected to this central group and not within their groups. Central model is a special case of centre-periphery model, where connections among peripheral groups are not allowed (Doreian et al, 2005). Research proposition that we derive from this knowledge is:

P8: Knowledge-based organizations have cohesive structure of relationships among members.

Analysis of block models according to geographical location partition (three subgroups) and departmental partition (four groups) revealed that the theoretical model that fits data the best is the model of cohesive groups. This statement can be supported both from analytical as well as substantive perspective, given the fact that it is knowledge based organization. We cannot claim that there is a central group of employees from whom all would like to learn, or that there is a hierarchy. Formulation of cohesive groups within the company is much more a result of geographical location than departmentalization. While they succeed to overcome interdepartmental barriers, they need to address issue of mechanisms for learning among various geographical locations.

\section{CONCLUSIONS}

Social network analysis of a learning network within the software company offered some insights regarding the research question how learning within organizations occurs. Learning needs to be seen both as a participation in practice community and a flow of previously acquired knowledge. Evidence for both sides of argument was found in our case. On one hand, learning often occurs in project settings and mainly involves transfer of tacit knowledge through participation. On the other hand, employees who are the most often seen as a source of learning are those with above average tenure within company and hence accumulated experience and knowledge. Analysing learning networks seems to be the best way to approach the complexity of the research question posed. Hence, we believe to have provided some initial indications that learning network metaphor could combine previously disparate acquisition and participation metaphor for organizational learning.

Stemming from the learning network theory, we observed a horizontal learning network that has egalitarian organizational structure, organically oriented learning processes and open content structure. On the basis of this case we offered several research propositions, which need to be further investigated in cases of companies from other 
countries, other industries, of different sizes etc. Nevertheless, we believe to have provided some support for the notion that experience of certain employee contributes to his/her knowledge and that others are more probable to learn from such a person. We also provide some evidence for the possible explanatory variables for learning: (1) physical proximity (shared office, geographical position), (2) complementarities in knowledge possessed, (3) complementarities in personal traits, and (4) similarity in level of expertise. Observing networks as a whole, we believe that there are at least two important determinants of density of relationships within the network: size and age - the greater the network, the lower the density, and the older, the denser.

From practice-oriented perspective social network analysis applied in learning context, can provide a strong management tool to find and reward central employees in organization, to develop the fit between formal and informal organizational structure, to support reward system renewal, to help understand organizational culture within the company, to help organize education and training programmes etc. It offers many measures, which are aimed at recognizing the most important employees from various perspectives, not just from the learning one. Having this knowledge, managers can better develop reward systems and motivational schemes for their employees. Knowing the structure of relationships within their organization, managers can also adjust their style on a democratic-autocratic continuum. From such an analysis significant implications for human resource professionals when planning educational and training schemes derive as well. They can better suit needs of the employees having that information. On the other hand, such a tool needs to be addressed with utmost care, since it can be very easily misused. It involves some ethical issues related to careful and concise interpretation of results.

Future work in the area will need to apply learning network to other settings in order to find additional support for the propositions offered. Valuable insights would come from similar analyses in companies of various sizes, different industries, other countries etc. in order to control for impact of various context variables. We acknowledge that our results apply only to knowledge-based organizations in a specific setting, while to allow for a generalization of implications further research endeavours are needed.

\section{REFERENCES}

1. Andrews, P. H. and Herschel, R. T. (1996): Organizational Communication-Empowerment in a Technological Society, Boston: Houghton Mifflin.

2. Batagelj, V., Mrvar, A., and Pajek (2005): 1.04 - Program for Large Network Analysis, http://vlado.fmf.unili.si/pub/networks/pajek (Accessed: 7.4.2005).

3. Bloch, S. and Bates, T. (1995): Employability, London: Kogan Page.

4. Dimovski, V. and Škerlavaj, M. (2004): Organizational Learning and Its' Impact on Financial and Nonfinancial Performance, Proceedings of $5^{\text {th }}$ Organizational knowledge, Learning and Capabilities conference, Innsbruck.

5. Doreian, P., Batagelj, V., and Ferligoj, A. (2005): Generalized blockmodeling, Cambridge: Cambridge University Press.

6. Easton, G. (1992): Industrial Network - A Review, in B. Axelsson, Easton, G.: Industrial Networks - A New View of Reality, London: Routledge.

7. Filipczak, B. (1995): You're On Your Own: Training, Employability, and the New Employment Contract, Training, 32(1):29-37.

8. Krebs, V. (2004): An Introduction to Social Network Analysis, http://www.orgnet.con/sna.html (accessed: 7.4.2005).

9. Lazega, E. (1992): The Micropolitics of Knowledge, New York: A. de Gruyter.

10. Mitchell. J. C. (1969): The Concept and Use of Social Networks. In J.C. Mitchell (ed.), Social Networks in urban situations, Manchester: University of Manchester Press.

11. Nooy, W. de, Mrvar, A., and Batagelj, V. (2005): Exploratory social network analysis with Pajek, New York: Cambridge University Press.

12. Poell, R. F., Chivers, G. E., Van der Krogt, F. J., and Wildermeersch, D. A. (2000): Learning-network Theory - Organizing the Dynamic Relationships between Learning and Work, Management Learning, 31(1): 25-49. 
13. Senge, P. M. (1990): The Fifth Discipline - The Art and Practice of the Learning Organization, New York: Doubleday Currency.

14. Tichy, N. M., Tushman, M. L., and Fombrun, C. (1979): Social Network Analysis for Organizations, Academy of Management Review, 4(4): 507-519.

15. Van der Krogt, F. J. (1998): Learning Network Theory - The Tension between Learning Systems and work Systems in Organizations, Human Resource Development Quarterly, 9(2): 157-177.

16. Wasserman, S. and Faust, K. (1994): Social Network Analysis, Cambridge University Press.

17. Wilson, A. L. and Cervero, R. M. (1997): The Song Remains the Same: The Selective Tradition of Technical Rationality in Adult Education Programme Planning Theory, International Journal of Lifelong Education, 16(2): 84-108.

Appendix A "Input And Output Degrees" and Appendix B "Brokerage Roles" are available from authors.

\section{$\underline{\text { NOTES }}$}




\section{NOTES}

